UDC 504.75.05

DOI: 10.15587/2706-5448.2021.238527

Article type «Reports on Research Projects»

\section{Svitlana Delehan-Kokaiko, Emilia Glyudzyk, Olesya Symkanuch}

\title{
INTEGRATED ASSESSMENT OF ATMOSPHERIC AIR POLLUTION BY THE EXAMPLE OF THE CITY OF UZHHOROD (UKRAINE)
}

The object of research is the processes of transformation of the ecological equilibrity of the structural and functional state of atmospheric air by the example of the city of Uzhhorod (Ukraine), as the border area, and the impact on the health of the population. One of the most problematic issues is the imperfection of methods for assessing the quality of air and its impact on the health of the population.

During the study, data from the Transcarpathian Regional Center of Hydrometeorology were used, the materials of statistical reporting of enterprises, the urban sanitary and epidemiological station, etc. Data is obtained relating to the influence of automobile transport in Uzhhorod, Transcarpathian region, on the quality of atmospheric air, as well as the negative consequences of the impact of excessive concentrations of pollutants in the air on the health of inhabitants of urbanized territories. The authors analyze the data on the concentrations of certain air quality parameters in 2019 and 2020. The ways to improve the ecological situation in Uzhhorod have been suggested, and the necessity of developing public control of air quality to preserve the health of Uzhhorod residents has been substantiated.

Due to the introduction of the proposed ways to improve the environmental situation in Uzhhorod, an increase in the living conditions of the population of border areas, in particular, Uzhhorod, improving the quality of atmospheric air of the investigated territories will be achieved. It is indicated to develop proposals for improving the methods of quality control of atmospheric air of border areas that will correspond to the standards of the European Union. This study is global due to the shapes of modern anthropogenic pressure, spontaneity, impulsivity and comprehensive validity of numerous factors implemented against the background of climate change. And it is requires new approaches in the scientific principles of organization of nature management, which will be based on an ecosystem approach in identifying and establishing biosafety of existing and latest pollutants.

Keywords: public control, air quality, air quality index, contaminant.

How to cite

Delehan-Kokaiko, S., Glyudzyk, E., Symkanuch, O. (2021). Integrated assessment of atmospheric air pollution by the example of the city Uzhhorod (Ukraine). Technology Audit and Production Reserves, 4 (3 (60)), 27-31. doi: http://doi.org/10.15587/2706-5448.2021.238527

\section{Introduction}

The relevant issue is the imperfection of methods for assessing the quality of air and its impact on the health of the population. For a comprehensive assessment of the effects of influence the total air pollution on the state of health of the population is needed comprehensive estimates of atmospheric air pollution [1, 2].

In his report, the UN Special Rapporteur, Mr. David Boyd, notes that clean air is a key component of the right to a healthy environment, along with clean water, adequate sanitation conditions, healthy food and a safe climate. The UN expert points out that air pollution is the cause of respiratory, infectious and heart disease, stroke, lung cancer and pregnancy-related complications. Children who inhale contaminated air are increasingly likely to develop asthma, chronic lung disease, stunted growth, diabetes, childhood obesity and mental retardation. At the same time, the issue receives insufficient attention, even though more than 150 states have pledged to respect and protect the right to a healthy environment by acceding to international treaties and enacting relevant laws [3]. The countries of the European Union are systematically making progress towards solving environmental problems, including those related to air quality, because air quality affects the health of the population on a global scale. The WHO air quality guidelines (AQGs) are intended for worldwide use but have been developed to support actions to achieve air quality that protects public health in different contexts. Air quality standards, on the other hand, are set by each country to protect the public health of their citizens and as such are an important component of national risk management and environmental policies. National standards will vary according to the approach adopted for balancing health risks, technological feasibility, economic considerations and various other political and 
social factors, which in turn will depend on, among other things, the level of development and national capability in air quality management. The guideline values recommended by WHO acknowledge this heterogeneity and, in particular, recognize that when formulating policy targets, governments should consider their own local circumstances carefully before adopting the guidelines directly as legally based standards. The process leading to the present revision of the air quality guidelines is summarized in the report of the WHO Working Group Meeting, which convened in Bonn, 18-20 October 2005 [4, 5].

The object of research selected the processes of transformation of the ecological equilibrity of the structural and functional state of atmospheric air by the example of the city of Uzhhorod (Ukraine), as the border area, and the impact on the health of the population.

At present, the assessment of atmospheric air pollution in Ukraine does not meet the norms of the European Union and is carried out taking into account the multiplicity of the total indicator pollution of normative marginal-permissible concentrations, and also includes characteristics of pollution and degree of security [6]. In the dynamics, only data of subacute observations can be obtained, where in several ingredients (carbon oxide, formaldehyde, nitrogen oxide, nitrogen dioxide, dust, etc.) are measured by maximum- time concentrations. Consequently, the sanitary control of atmospheric air through complexity and high cost is not carried out by all ingredients and with different levels of the averaging of the results. In analyzing the environmental situation, the synergistic action of substances in complex mixtures is not taken into account, in case when their concentration in the air is lower than the threshold of detection (for example, at a level to $0.7 \mathrm{MPCs}$ ). That is, pollutants that are in the air at $70 \%$ of the permissible content are not taken into account, although many of them exhibit specific properties, in particular, carcinogenic, allergenic and others, respectively, adversely affect the inhabitants of the border areas [7, 8].

Thus, there are problems in determining the impact on the human body of chemicals entering the atmosphere, in standard indicators, which does not allow to accurately assess the risk of air pollution to human health, to objectively analyze the correlation between the level of toxic effects of individual components of air pollutants and the general health of the population. It is necessary, along with improving sanitary control over the air, to pay more attention to objects of pollution, as well as to provide access to relevant information on air quality to urban residents. Access to information on air quality will allow residents of urban areas to adjust their activities during the day and thus protect their health. After all, the danger of air pollution is a cross-border problem.

The aim of research is to conduct a comprehensive assessment of atmospheric air pollution using the example of the city of Uzhhorod (Ukraine).

\section{Methods of research}

During the study, data from the Transcarpathian Regional Center of Hydrometeorology, the materials of statistical reporting of enterprises, the urban sanitary and epidemiological station were used.

To compare the toxicity of emissions in a particular area, it is necessary to determine the multiplicity of excess emissions of each pollutant in the area to its maximum allowable concentrations or relatively safe levels of exposure, after which these values are added to all ingredients. This information allows to assess the total toxicity of emissions in the area, the specific contribution of individual substances to their overall toxicity.

For calculation, the average daily maximum permissible concentrations are used as standards, the effect of which depends not only on the concentration of the substance in the air, but also on the period of time during which it was inhaled. For substances that are characterized only by a reflective effect and due to the lack of average daily maximum permissible concentrations, it is necessary to use the maximum single maximum permissible concentration.

To assess the potential risk of specific effects in the residents of Uzhhorod under the influence of chemical air pollutants, a similar calculation was made for groups of substances in emissions that characterize the toxic effects of individual components: carcinogens, allergens, etc.

The list of substances that have carcinogenic properties is given in «List of substances, products, production processes, household and natural factors that are carcinogenic to humans», approved by the order of the Ministry of Health of Ukraine from 13.01.2006 No. 7, as well as in other regulations [9].

This information allows more objectively identify the range of chemicals that determine the toxicity of emissions into the territory and assess the feasibility of their control in the air. To assess the degree of air pollution, it is also necessary to calculate the specific toxicity of all emissions per unit area.

\section{Research results and discussion}

In addition to being the regional center of Transcarpathia, Uzhhorod is also one of the most attractive tourist centers in Ukraine. Annually Uzhhorod attracts numerous Ukrainian tourists and owing to its convenient geographical location it draws a lot of tourists from the EU countries. This causes a permanent excessive anthropogenic load on the atmospheric air. According to statistics, every third resident of Uzhhorod owns a car, therefore the use of public transport is unpopular. It is worth noting that according to the statistical data of the Transcarpathian Regional Center for Hydrometeorology, almost $70 \%$ of the days of the year are characterized by windless conditions in Uzhhorod, i. e., there is no decrease in the concentration of contaminants in the air of the city by means of dispersion. Thus, residents of this city and its guests inhale a lot of carcinogenic substances, the level of which periodically exceeds the maximum allowable concentrations.

Regular observations of atmospheric air pollution in the city of Uzhhorod have been conducted at two stationary pollution observation posts (POP) located in residential and industrial areas of the city at addresses: POP-1 - 2, Svobody ave. (48 37'13.7"N $\left.22^{\circ} 17^{\prime} 06.7^{\prime \prime} \mathrm{E}\right)$ as well as POP-2 - 2, Serhiy Martyn str. (48 35'55.0"N 22¹8'43.7"E) [10].

Fig. 1 demonstrates the averaged data (observation data from 2 stationary stations have been used) of changes in the air basin of Uzhhorod for the period from 2019 to 2020. The sampling has been carried out 2-4 times a day, excluding weekends. The main contaminants of atmospheric air (dust, nitrogen dioxide, nitrogen oxide, carbon monoxide), and specific ones (e. g., formaldehyde) have been considered. 

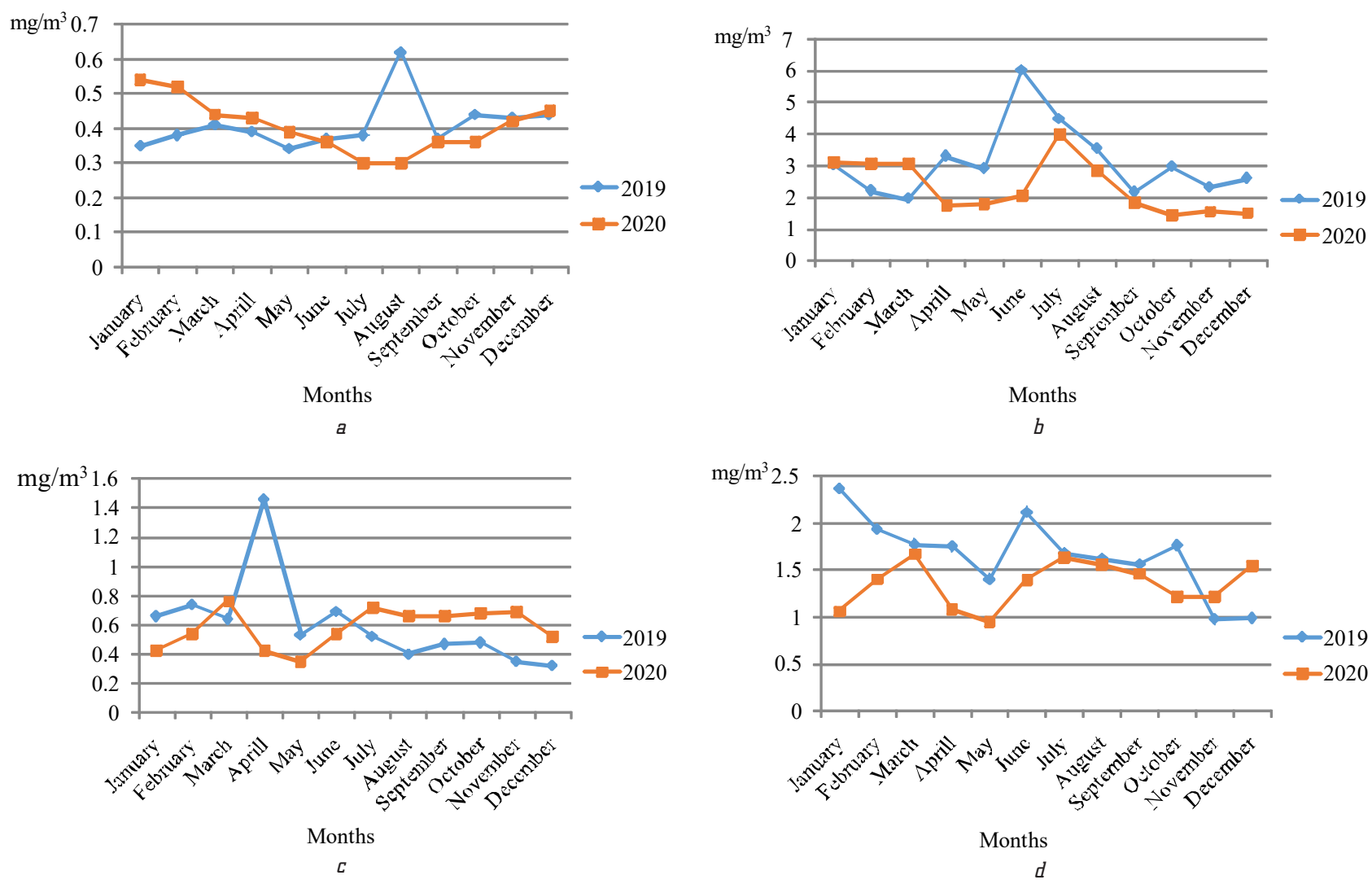

Months
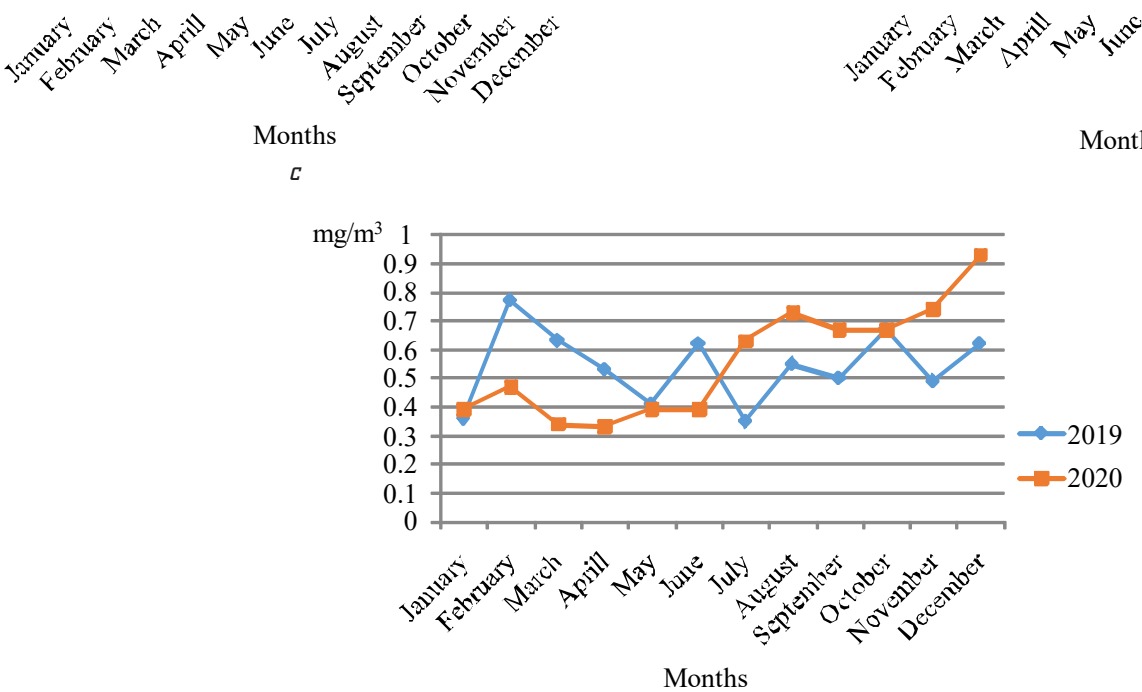

e

Fig. 1. Dynamics of changes in certain air quality indicators in the city of Uzhhorod:

$a$ - carbon monoxide; $b$ - formaldehyde; $c$ - nitric oxide; $d$ - nitrogen dioxide; $e$ - dust

According to the research results, the carbon monoxide content for 2020 from June to November is lower compared to that in 2019. It should be noted that the lowest values of this indicator for 2020 are observed in July and August, in contrast to 2019, where its concentration for July reached the maximum value. The decrease in the $\mathrm{CO}_{2}$ content in 2020 can be conditioned by the introduction of quarantine countermeasures against COVID-19 all over the world, which led to a decrease in the intensity of industrial production and restrictions on traffic movement. Such changes in the state of atmospheric air confirm the determining role of anthropogenic influence on the formation of the greenhouse effect and the negative climatic changes as well as the total contaminant impact on the surface air layer.

The concentration of formaldehyde in 2020, as indicated by the study, is significantly lower from April to December compared to 2019. Moreover, the lowest concentration of this indicator in the atmospheric air in Uzhhorod in 2020 is observed in December, which is obviously associated with a decrease in the number of vehicles in connection with COVID-19 (it is the burning of methane, which is used as fuel for cars, causes the production of this hazardous substance).

A study of nitrogen oxide content shows that the lowest concentration of this indicator in 2020 is observed in April, May, June, with a gradual increase in its content during the following months and exceeding values for 2019 beginning with July. The data regarding nitrogen dioxide concentrations from 2019-2020 has a different pattern, with a decrease for 2020 throughout the year, the exception being November and December (there is an increase in nitrogen dioxide concentration in November and December in 2020 compared to that in 2019).

The dynamic of changes in dust content in the air is of particular interest. Fig. 1 shows that during the study 
period from January to June 2020 there is a decrease in the dust content in the atmosphere compared with the values for 2019. Thus, from July 2020, it is possible to observe a gradual increase in the index to its maximum value in December compared to 2019 [11].

Based on data from the Transcarpathian Regional Center for Hydrometeorology, the atmospheric air pollution index for Uzhhorod during 2019-2020 has been calculated, which is presented in Fig. 2.

Therefore, comparing the air pollution index in 2019 and 2020 in Uzhhorod, it is possible to conclude about the worse air quality indicators compared to the same months in 2020, which may be attributed to many reasons, in particular the negative impact of the number of vehicles and the type of fuel that is predominantly used.

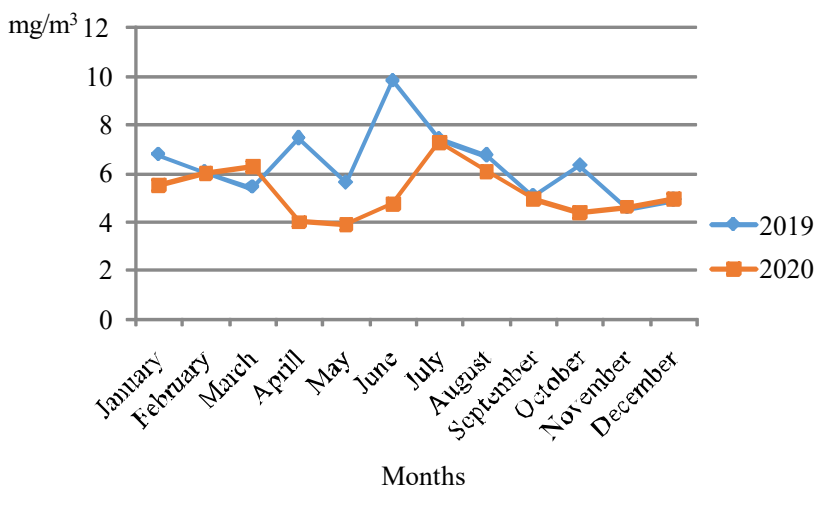

Fig. 2. Atmospheric air pollution index of Uzhhorod during 2019-2020

It should be noted that two stationary observation posts are not sufficient to obtain air quality results that will reflect the real state of the air environment in Uzhhorod since Uzhhorod is inhabited (according to official data of the Ministry of Finance) by 115512 people as of 1.01 .2020 , with the city covering an area of $41.56 \mathrm{~km}^{2}$ [12].

Besides, Uzhhorod is the biggest transport junction of the Transcarpathian region, which is crossed by a number of European roads - E50, E58, E573, as well as international highways M06, M08 and the highway of national importance H13. Uzhhorod also hosts the railway station and the airport. Moreover, the city has a checkpoint on the border with Slovakia Uzhhorod - Vyšné Nemecké [10].

In countries with a high degree of environmental safety, an important stage in improving the health of city residents have the ability to monitor the state of air quality in real time and, accordingly, to adjust their activities in public spaces. In fact, environmental monitoring has its own specific requirements and main tasks that should be observed for adequate assessment and prediction, determining the degree of anthropogenic impact, identifying factors and sources of contaminant effluence.

Thus, the main ways of solving the problem of atmospheric air pollution in Uzhhorod, on the part of the authorities, should include:

- providing public control over the state of atmospheric air in real time, which will allow city residents to regulate their activities in certain locations (now measurements are conducted at two stationary posts which is extremely insufficient);

- dissemination of information in the press, social networks about the negative impact of polluted air on health;
- architectural and planning measures, arrangement of green areas, since green areas serve as effective biofilters; - development of projects to reduce the intensity and organization of traffic;

- creation of bicycle infrastructure in the city, which will enable many residents to use bicycles more often for daily needs and recreation.

Scientific and practical results of this article will have: - organizational and economic results (improvement of mechanisms for economic regulation of environmental objects, methods and control systems for transboundary airspace);

- social results (substantiation of conditions for improving the health of the population);

- environmental results (rational nature management and environmental stability).

The introduction of the above measures, will give expected benefits from their implementation and significantly exceed the costs of their funding. In Ukraine, there is a small number of air quality surveillance points, respectively, there is a shortage of data that can be integrated into the system of public monitoring of Ukraine, as well as to the monitoring systems of neighbouring countries of the European Union, in particular Slovakia, Hungary, Poland and Romania, since part of the investigated territories are transboundary. Implementation of the above measures and arrangement of the urban territory with sufficient number of automatic air quality surveillance points will contribute not only to increase the monitoring efficiency within the Carpathian Euroregion, but also to improve the good-neighbourly relations in the environmental sphere between Ukraine and the European Union.

When studying the state of air quality, it should be taken into account that the scattering in the atmosphere of emissions from chimneys and ventilation devices occurs according to the laws of turbulent diffusion. The following factors have a significant influence on the scattering process: the state of the atmosphere, physical and chemical properties of the emitted substances, the height and diameter of the emission sources, the location of the sources, and the terrain etc.

It is important to take into account the possible effects of transboundary diffusion of polluted air masses. That is why further research on air quality will be related to the study of the situation in the neighboring countries (Slovakia and Hungary), as well as the study of the EU experience in solving the problem of air pollution in cities.

\section{Conclusions}

The study found that among the pollutants emitted in Uzhhorod, due to their toxic properties and intensity of release into the atmosphere, the following ingredients have a major impact on public health: carbon monoxide, formaldehyde, nitrogen oxide, nitrogen dioxide, dust. Atmospheric air pollution index of Uzhhorod during 2019-2020 was the highest: in June 2019 - 9.79, and in July $2020-7.29$. Atmospheric air pollution index of Uzhhorod during 2019-2020 was the lowest: in November 2019 - 4.55, and in May 2020 - 3.87.

However, the list of components that can harm the health of the population is much larger and requires detailed study. 
The specific emission toxicity indicators obtained in the study can be used for an objective comparison of Uzhhorod with other cities of Ukraine. For example formaldehyde: the lowest points let's observe in March $2019-1.94 \mathrm{mg} / \mathrm{m}^{3}$, and in October $2020-1.45 \mathrm{mg} / \mathrm{m}^{3}$. But the highest concentration of formaldehyde in the city Uzhhorod let's observe during summer months from 6 to $3.52 \mathrm{mg} / \mathrm{m}^{3}$ in 2019, and in July and all winter months 2020 from 3.99 to $3.06 \mathrm{mg} / \mathrm{m}^{3}$. There are only two regular stationary pollution observation posts (POP) located in residential and industrial areas of the city, but it's not enough. The results of the study will be useful in developing measures to improve the environmental situation of the city Uzhhorod, as well as for the introduction of public air quality control to preserve the health of Uzhhorod residents.

European experience in solving ecological problems is great and it is possible to observe and use their best practices in Ukraine. On the other hand results of this article will be useful for European scientists too because ecological problems has no borders.

\section{References}

1. Mukhin, V. V., Putilina, O. N., Teplovaia, T. E., Kozlova, O. I. (2003). Novye podkhody k otsenke zagriazneniia atmosfernogo vozdukha po rezultatam analiza vybrosov promyshlennykh predpriiatii. Dovkillia ta zdorov'ia, 2, 53-57.

2. Rakhmanin, Iu. A., Taranov, A. A., Novikov, S. M. et. al. (2003). Metodologicheskie problemy otsenki riska zdoroviu naseleniia obuslovlennogo chrezvychainym vozdeistviem faktorov okruzhaiuschei sredy. Biul. Vostochno-Sibirskogo NTS SO RAMN, 2, 22-24.

3. Pravo na chyste povitria vazhlyvo tak samo, yak i inshi prava liudyny (2019). Mizhnarodne publichne pravo. Available at: https:// ukrainepravo.com/international law/public international law/ pravo-na-chyste-povitrya-vazhlyvo-tak-samo-yak-i-inshi-pravalyudyny $/$ ? month $=08 \&$ year $=2019$

4. WHO Regional Office for Europe. Available at: http://www. euro.who.int
5. World Health Organization. Regional Office for Europe (2000). Air quality guidelines for Europe. World Health Organization. Regional Office for Europe. Available at: https://apps.who.int/ iris/handle/10665/107335

6. Rukovodstvo po kontroliu zagriazneniia atmosfery. RD. 52.04 . 186-89 (1991). Available at: https://docs.cntd.ru/document/ 1200036406

7. Galeev, K. A., Khakimova, R. F. (2002). Sviaz mezhdu kontsentratsiiami v atmosfernom vozdukhe khimicheskikh veschestv rasprostranennostiu allergicheskikh zabolevanii. Gigiena $i$ sanitariia, 4, 23-24

8. Hots, T. Yu. (2004). Zakhvoriuvanist naselennia Ukrainy na bronkhialnu astmu i poshyrenist alerhennykh chynnykiv povitria. Dovkillia ta zdorovia, 3, 8-10.

9. Perelik rechovyn, produktiv, vyrobnychykh protsesiv, pobutovykh ta pryrodnykh faktoriv, kantserohennykh dlia liudyny (2006) Nakaz Ministerstva okhorony zdorozia Ukrainy No. 7. 13.01.2006. Available at: https://zakon.rada.gov.ua/laws/show/z0100-06\#Text

10. Transportna infrastruktura Zakarpatskoi oblasti. Available at: https://uk.wikipedia.org/wiki/\%D0\%A3\%D0\%B6\%D0\%B3\% $\mathrm{D} 0 \% \mathrm{BE} \% \mathrm{D} 1 \% 80 \% \mathrm{D} 0 \% \mathrm{BE} \% \mathrm{D} 0 \% \mathrm{~B} 4$

11. Zakarpatskyi oblasnyi tsentr $z$ hidrometeorolohii. Available at: http://gmc.uzhgorod.ua/

12. Chyselnist naselennia v m. Uzhhorod stanom na 1.01.2021 roku. Available at: https://index.minfin.com.ua/reference/people/town/ uzhgorod/

$\triangle$ Svitlana Delehan-Kokaiko, PhD, Associate Professor, Department of Ecology and Environmental Protection, State Institution of Higher Education «Uzhhorod National University», Uzhhorod, Ukraine, ORCID: https://orcid.org/0000-0002-7904-2013, e-mail: svetlanadel1@ukr.net

Emilia Glyudzyk, Postgraduate Student, Department of Ecology and Environmental Protection, State Institution of Higher Education «Uzhhorod National University», Uzhhorod, Ukraine, ORCID: https://orcid.org/0000-0002-6751-7157

Olesya Symkanuch, PhD, Associate Professor, Department of Pharmaceutical Disciplines, State Institution of Higher Education «Uzhhorod National University», Uzhhorod, Ukraine, ORCID: https:// orcid.org/0000-0002-9948-1742

$\triangle$ Corresponding author 